\title{
О ЗОЛОТЕ НЕ КОЛЧАКА: ИСТОРИКО-ГЕОПОЛИТИЧЕСКАЯ ИНТЕРПРЕТАЦИЯ
}

С позиций геополитики интерпретируется проблема золотого запаса Российской империи в годы гражданской войны. Золото было и остается серьезным ресурсом мировой политики, поэтому борьба за его обладание ведется всегда. В статье рассматривается роль союзников России по Антанте в развязывании Гражданской войны и стремлении вывести золотой запас государства за пределы страны. Исследуются основные события, произошедшие на пути следования эшелона с золотом от станции Нижнеудинск до Иркутска, завершившиеся его передачей представителям советской власти и возвращением золотого запаса в Казань, а затем Москву. Фиксируются разночтения в исторической литературе и документах, имеющие отношение к данной теме, 
что создает почву для различных околонаучных версий. Актуализируется проблема необходимости исторических исследований по вопросу о судьбе золота СССР, субъектах его присвоения.

Ключевые слова: золотой запас, Колчак, «союзные государства», гражданская война.

A. V. SHALAK

\title{
ABOUT KOLCHAK AND GOLD RESERVES, WHICH DIDN'T BELONG TO HIM: INTERPRETATION FROM THE HISTORICAL AND GEOPOLITICAL POINT OF VIEW
}

\begin{abstract}
The problem of gold reserves of Russian Empire during the civil war is interpreted from the geopolitical perspectives. Gold has been and remains one of the most serious resources of the world policy that is why the struggle for its use is endless. This article looks at the role of Russian allies of the Entente in waging the Civil war and in striving to put gold reserves out of the State. The key events are highlighted, which were happened on the way of the train with gold from Nizhneudinsk to Irkutsk, and which were ended up by the gold transferring to the Soviet government officials, and then from Kazan to Moscow. There is inconsistency in historical materials and documents, which are related to this topic, and as a result the appearance of pseudoscientific theories. The necessity of historical research about the USSR gold and subjects of its appropriation is still a current issue.
\end{abstract}

Keywords: gold reserves, Kolchak, «Allied States», Civil war.

Многое изменилось в отечественной историографии за постсоветские десятилетия. Радикально поменялись выводы по многим темам. Особенно это касается ключевых вопросов нашей истории, к которым относится тема революции и Гражданской войны. Думается, что данная ситуация надолго, поскольку она имеет отношение к психоисторической войне, главной целью которой является установление контроля над общественным сознанием. Общественное сознание, его гражданский потенциал в условиях информационной войны является главным потенциалом любого государства. Поэтому борьба за историю, за символический капитал, будет только обостряться. В России эту проблему усугубляет раскол нашей культуры, что только осложняет процесс интеграции общественного сознания и поляризует оценки относительно прошлого. Отсутствует в России консолидирующая национальная система ценностей, а «методологический хаос» является естественным сопровождением данного процесса. Поэтому, казалось бы, раннее изученные и практически закрытые вопросы историографии обрастают новыми подробностями и в условиях смены политического и правового поля России получают неожиданное продолжение. 
К такому историческому «спектаклю» имеет отношение и так называемое «золото Колчака». По непонятным причинам, часть золотого запаса Государственного банка Российской империи стала именоваться «золотом Колчака». Это все-равно, что золотой запас современной России именовать «золотом Путина». Политическая звезда Колчака была слеплена искусственно. Участник экспедиций по исследованию северных морей и специалист в области минных заграждений неожиданно вознесся на политический олимп. За каких-то полтора года Колчак сменил четыре мундира. Вначале он обнулил присягу российскому монарху и самым первым присягнул на верность Временному правительству. Знаки различия, введенные Временным правительством, он затем заменил на «мундир английский», перейдя на службу британскому правительству. А затем с подачи «союзных государств» примерил на себя мундир «Верховного правителя Всероссийского правительства» и в этот же день ему было «присвоено» звание адмирала [13, с. 104-109]. Человек, не имеющий ни программы, ни каких-либо заслуг в борьбе с большевизмом, мало что понимающий в сухопутных операциях и политических интригах был поставлен во главе белого сопротивления интервентами как наиболее удобная и контролируемая ими фигура. Колчак действует в интересах Англии, и прекрасно это осознает. В письме своей гражданской подруге А. Тимиревой от 16 марта 1918 г. из Сингапура он сообщает, что получил пакет «с распоряжением английского правительства вернуться немедленно в Китай ... для работы в Маньчжурии и Сибири» И дальше он пишет: «Моя миссия является секретной, хотя я догадываюсь о ее задачах и целях» [10, с. 264]. «Борьба за единую и неделимую Россию», за что якобы выступал Колчак англосаксов абсолютно не привлекала. Им нужна была слабая, зависимая от них и контролируемая ими Россия. Именно поэтому им так важно было развязать в ввергнутой в хаос Временным правительством стране еще и затяжную, на сколько это возможно, Гражданскую войну, чтобы окончательно обескровить ее геополитический потенциал. «Разделяй и властвуй» и «война чужими руками» являются излюбленными геополитическими приемами англосаксов, в которых им нет равных и сегодня. В этот англосаксонский капкан Россия дважды попадала в XX в.

Поэтому возвеличивать таких личностей как Колчак, можно либо по наивности, либо сознательно, играя на стороне геополитических противников России. Не случайно, когда судили правительство Колчака в конце мая 1920 г. в Омске одним из основных пунктов являлось обвинение в расхищении и передаче иностранным правительствам достояний государства, в том числе и золотого запаса [5, с. 269; 3, с. 81-85].

Золото - это серьезный ресурс в мировой политике. Поэтому борьба вокруг него была, есть и будет. Именно с позиций геополитики нужно интерпретировать проблему золотого запаса Российской империи в период гражданской войны. 
История золотого запаса Российской империи, получившая свою развязку в Иркутске в 1920 г., берет свое начало в 1915 г. В начале Первой мировой войны русская армия, потерпев ряд поражений, была вынуждена отступать. Немцы приблизились к Петрограду. Встал вопрос о сохранности государственного золотого запаса и было принято решение эвакуировать золото в далекие от фронта тыловые города. В начале 1915 г. началась эвакуация государственных ценностей из Петрограда в Казань и Нижний Новгород. Затем в Казань перевезли еще золото из Воронежа, Тамбова, Самары, Курска, Могилева, Пензы. В итоге в городе сконцентрировалось на 600 млн рублей золота и почти на 200 млн рублей серебра, что составляло более половины золотого запаса Российской империи [2]. Золото оставалось в глубоком тылу и после того, как власть в России перешла к большевикам. Однако после восстания чехословацкого войска 25 мая 1918 г., с которого начинается Гражданская война, большевистское правительство приняло решение эвакуировать золотой запас из Казани. Направленные сюда представители советского правительства успели вывезти 4,6 т золота [9]. 6 августа 1918 г. отряд под командованием подполковника В.А. Каппеля захватил город и находящийся здесь золотой запас. 16 августа захваченное золото на двух пароходах под особой охраной отправили в Самару. Вскоре Красная Армия начала успешное наступление против сил КОМУЧа и чехословаков, освободила ряд городов и приблизилась к Самаре. В конце сентября КОМУЧ начал спешную эвакуацию золота из Самары в Уфу и затем в Омск. Здесь уже находился штаб и правительство А.В. Колчака, которого с подачи «союзных государств» все антисоветские группировки признали «Верховным правителем России». В ноябре 1918 г. эшелоны прибыли в Омск, и золотой запас был размещен в Омском отделении Госбанка России.

Только спустя полгода, в мае 1919 г. группа банковских работников начала пересчет золота, поступившего в распоряжение правительства Колчака. После пересчета было установлено, что всего в Омске находилось 505 т золота в виде российской и иностранной монеты, кружков, полос и слитков [9]. Большинство исследователей приводят эту цифру, хотя вряд ли можно было за такое короткое время и такими силами точно подсчитать запасы золота. Исследователь В. Серебенников приводит другие цифрры - 496,873 т золота [11, с. 19]. Здесь же хранилось золото, принадлежащее Главной палате мер и весов, а также золотые самородки из хранилищ Горного института, не включенные в государственный запас. Это также вносит путаницу в производимые расчеты. Сколько было всего вывезено золота и сколько исчезло его до мая 2019 г., с учетом того, что золото поступало в Казань и из других городов России, установить точно не представляется возможным.

Просуществовало «Правительство Колчака» до середины ноября 1919 г., т.е. в пределах года. О его какой-либо полноценности и само- 
стоятельности не приходится говорить. Основная транспортная коммуникация контролировалась чехословацкими легионерами, которые подчинялись французскому командованию. Планировать и осуществлять любые военные компании, хозяйственную деятельность можно было только с одобрения «союзников». После того, как Ставка Колчака покинула Омск, отступление его армии приняло характер хаотичного бегства. Возможность осуществлять управление была окончательно утеряна. Бегство самого «Верховного Правителя России» обернулось окончательной утратой какого-либо авторитета как в своих войсках, так и среди «союзников». Политическое будущее Колчака после этого было предрешено. После этого Колчак был интересен «союзникам» только в том отношении, что с ним следовал эшелон с частью золотого запаса России. Это придавало особую специфику и важность начавшемуся железнодорожному марафону.

Вокруг эшелона с золотом закручивается политическая интрига. Отказаться от такого лакомого куска «союзники» не могли и действовали весьма согласованно. Еще царское правительство переправило в Лондон 440 т золота, в счет которого были открыты кредиты на приобретение вооружения и обмундирования для действующей армии [9]. Однако возобновить поставки под золото царского правительства Колчак не мог, потому что его власть Антантой, Японией и США не была признана Всероссийской, т.е. правопреемником царского и Временного правительства он не являлся. И это не случайно, поскольку в этой ситуации снабжение армии Колчака могло осуществляться только за счет золотого запаса, оказавшегося у него в руках. Пока «союзники» контролировали ситуацию через Колчака, огромная часть золотого запаса перекочевала во Францию, Англию, США и Японию.

За поставки оружия армии Колчака, а также под залог таких поставок его правительство рассчитывалось золотом. Союзников такая ситуация абсолютно устраивала, никакой безвозмездной помощи по идейным соображениям не было. Темпы поставок золота были таковы, что если бы Колчак оказался способным продержаться еще год - полтора, то возможно практически все золото России, имеющееся в его распоряжении, утекло бы в закрома «союзных государств» на вполне законных основаниях. Но ситуация стала быстро меняться, армия Колчака разбегалась, «Верховный правитель Всероссийского правительства» также подался в бега. В таких условиях прежняя схема в отношении грабежа золотого запаса не работала. Поэтому остающийся золотой запас под каким-либо благовидным предлогом нужно было вывезти за пределы России и упрятать в контролируемые банки. Наибольший интерес к такой схеме проявили дальновидные американцы. Еще 3 сентября 1919 г. государственный секретарь США Лансинг писал американскому консулу в Харбине Дженкинсому о необходимости перевезти золото в здание американской 
миссии в Пекине. Американцы в этом случае обещали «в целостности и сохранности» вернуть золото тому правительству, которое окажется преемником Омского и «создаст в будущем стабильную политическую систему на всей территории России... С золотом связана возможность влиять на развитие событий в России...» [8, с. 145]. При этом, с их точки зрения, перевозка золота могла быть осуществлена только под контролем чехословацких войск, «... так как вероятно, что Семенов и его банды попытаются присвоить его...» [8, с. 146].

В случае реализации американского плана сохранялась бы прежняя схема, при которой в условиях затяжной гражданской войны золото утекало в банки «союзников» за различные услуги. Правительство Колчака также твердо намеривалось вывезти золотой запас за границу. Перед отправкой было разослано распоряжение о беспрепятственном пропуске поезда с золотом до Владивостока, а сотрудники банка, которые сопровождали груз получили соответствующие проездные документы [9]. Однако ситуация быстро менялась. Армия Колчака разваливалась. Единственной организованной силой, способной сопроводить эшелон с золотом, было чехословацкое войско. Другой силы у «союзников» к этому времени не было. Свои войска под удары Красной армии они подставлять не решились, и к этому времени основная часть воинских формирований Англии, Франции и США благополучно покинула пределы России. Однако, даже если бы чехам удалось оторваться от наступающей Красной армии, то им бы на этом пути пришлось столкнуться с интересами Японии, которая имела самый крупный контингент вооруженных сил на территории России на пути следования золотого запаса. Не упустили бы своего шанса банды Семенова, которые уже до этого сумели прибрать к своим рукам один из четырех эшелонов с золотом, отправленных во Владивосток для оплаты за предполагаемые поставки оружия. Могли создать серьезные проблемы чехам партизанские отряды, которыми руководили в основном большевики. Не обученные, плохо вооруженные, не очень дисциплинированные, они не могли организовать серьезный заслон против чехов. У них не было возможности взорвать байкальские тоннели, которые усилено охранялись семеновцами, а затем чехами. На линии там курсировали бронепоезда и эшелоны японцев. Работы же по подрыву тоннелей требовали длительного времени, подготовленных минеров и большого количества взрывчатки. Но, как отмечал один из руководителей Иркутского революционного комитета А.Г. Нестеров, партизанам было по силам создать угрозу артиллерийского обстрела железнодорожных путей, взорвать мелкие мосты, нависающие над железнодорожными путями горные откосы [7, с. 132-133]. Их сил было достаточно, чтобы затормозить, либо даже остановить на длительное время движение эшелонов с чехами. Борьба с партизанами могла принять затяжной характер. Она бы стимулировалась и произволом чехов вдоль железной 
дороги, поскольку окружающие населенные пункты становились объектом грабежа продовольствия. Недовольство местного населения в этом случае также бы вело к нарастанию актов саботажа на железной дороге. Задержка в движении для чешских легионеров могла перерасти в катастрофу в условиях зимы и наседающей по пятам Красной Армии.

В такой ситуации золото становилось разменной монетой за безопасное перемещение чехов в переговорах с теми политическими силами, которые представляли реальную и наибольшую угрозу для их безопасного передвижения. Географически эпицентром событий стал участок железной дороги от Нижнеудинска до г. Иркутска. Именно здесь происходят основные события, связанные с дальнейшей судьбой эшелона с золотом.

Вопрос о золоте возникает 3 января 1920 г. после того, как принято решение об устранении Колчака. С Колчаком не церемонятся: его охрана разоружается, а самому Колчаку «предлагается» прицепить свой вагон к любому чешскому эшелону следовать в Иркутск под охраной чехов. Одновременно с этим принимается решение о передаче золота под охрану «Чешско-Словацких войск». Председателем комиссии назначается представитель союзных войск капитан Блага Олдржих и еще два офицера из того же 1-го «Ударного батальона». Представители Колчака золото должны передавать в присутствии местных жителей, «пользующихся всеобщим доверием» [7, с. 7]. В состав комиссии от населения вошли Е. Огородов (представитель Уездного Земства), Н. Лунев (представитель гарнизона г. Нижнеудинска), В. Мунькин (представитель от служащих и рабочих депо Нижнеудинска [7, с. 9].

Документально факт передачи золотого запаса фиксируется в Нижнеудинске, где Колчак был арестован. Золотой запас, который следовал в пути вместе с ним, передается под охрану чехословацкого корпуса. Передавал его под охрану комендант эшелона Арбатский. На руках у него был только акт о приеме золота в г. Омске в эшелон от 7 ноября 1919 г., из которого следует, что точных данных о золотом запасе не имеется. Было просто зафиксировано, что золото находится в 29 вагонах с количеством ящиков 5154 и мешков в количестве 1678 [7, с. 8]. Ящики и мешки не вскрывались, вес находящегося в них золота не фиксировался. В документе отмечается что по ходу следования изменился состав вагонов и находящихся в них ящиков с золотом. В Ново-Николаевске в состав были загружены еще два ящика с золотом. Как они там оказались, с чем связано изменение состава вагонов в документе не фиксируется.

Арбатский утверждает, что книги с учетом золотого запаса находятся в Центральном Банке г. Иркутска. Как они там оказались в отрыве от эшелона, документ так же не дает никакой информации.

Интересна реакция представителей общественности, которые заявили, что акт о передаче подпишут только в том случае, если будет 
определен вес золота. На это им было заявлено, что они не полноценные члены комиссии, а только «свидетели». После чего они покинули заседание. Событие это происходит 4 января. В конечном итоге золото передается без представителей общественности. Как явствует из отчета представителя политического центра в Нижнеудинске чешской комиссии передано до «30 тыс. пудов золота» [7, с. 10]. В следующих переговорах с членом Нижнеудинского политического бюро Павловым утверждается, что в поезде запасы золота свыше 30 тыс. пудов [7, с. 11]. Очевидно, что точными данными о количестве золота никто не располагает. При этом речь в переговорах идет и о получении допуска в вагон Колчака, в котором по сведениям члена Нижнеудинского Политического бюро Аверьянова находится несколько ящиков с золотом [7, с. 9].

Под «бдительной» охраной чехов золото начинает пропадать еще на пути к Иркутску. 12 января на ст. Тыреть обнаруживается, что один из вагонов вскрыт и пропало 13 ящиков с золотом [7, с. 12]. Из 200 ящиков в вагоне оказалось 187. Вес каждого ящика условно оценивается в 3,5 пуда. При этом, как явствует из его сообщения, по факту кражи были составлены три акта: чиновниками Госбанка, чешской охраной и представителями политцентра. Различия в актах оказываются «существенны». Это означает, что данные о 13 похищенных ящиках условны. Точными данным на этот момент никто не владеет. На ст. Половина представитель Сибполитцентра Павлов сообщает, что по его данным еще 13 ящиков с золотом было изъято в Красноярске не понятно по чьему распоряжению, 20 ящиков изъято в Камышете. Последние 20 ящиков, как следует из опроса солдат, охранявших эшелон, вернули в эшелон Колчака обратно [7, с. 15]. Затем, когда золото будет приниматься от чехов в Иркутске, два из двадцати этих ящиков, находившихся непосредственно в вагоне Колчака, будут проверены. Мешки с золотом в ящиках были опечатаны, никаких нарушений комиссия не обнаружит [7, с. 95]. На пути от Омска до Нижнеудинска, утверждает Павлов, из-за крушений и поломок производилась неоднократная разгрузка золота и «даже сдача некоторых ящиков в эшелон Адмирала Колчака» [7, с. 23]. По его версии золото могло быть похищено и до Нижнеудинска. К этому могли быть причастны чиновники Госбанка, сопровождавшие золото. Факт пропажи мог быть просто имитирован срывом пломб на ст. Тыреть.

Первоначально вся вина возлагалась на русский караул, который непосредственно охранял данный вагон. Начальник эшелона золотого запаса Государственного банка Арбацкий заявил о ненормальности такого подхода, поскольку к краже могли быть причастны и чехи. Однако в отношении их никаких оперативных действий в плане расследования не предпринималось [7, с. 34]. Чины Банка и ревизионного наблюдения не имели возможность самостоятельно производить внешний осмотр эшелона. Им не сообщались пароли, без всякого предупреждения про- 
изводилось передвижение эшелона, изменение его вагонного состава. В частности, в рапорте старшего ревизора Н. Никольского от 30 января 1920 г. отмечается, что в ночь на 30 января в состав эшелона был введен вагон с неизвестным грузом [7, с. 40]. Чехи действовали без оглядки на кого-либо: брали на станциях любые паровозы, меняли составы, самостоятельно планировали передвижение. Поэтому в пути эшелон подвергался разнообразным выемкам и перегрузкам, менялся не только состав, но и его охрана. Несколько вагонов с золотом имели явные признаки повреждений. Отказ чехов на перезагрузку золота в другие вагоны мотивировался возможностью боевых действий, поэтому такая работа рассматривалась как «несвоевременная» [7, с. 73].

Полноценная охрана поезда была налажена только по его прибытию в Иркутск. Поезд с золотом был поставлен в тупик, окутан проводами и сигнализацией. Для большей безопасности была разобрана стрелка и вынуты подшипники из колес вагонов [4, с. 113]. Вопрос о перегрузке золота в неповрежденные вагоны и одновременной более тщательной проверке поврежденных помещений и ящиков, вынимавшихся из вагона или перегруженных после крушения был положительно решен только 22 января в присутствии представителей чехов и английского вице-консула [7, с. 41]. Из актов проверки следует, что в акте № 4 от 14 ноября 1919 г., составленного в Омске, количество ящиков, погруженных в вагон 566027 не указано и в пути следования ни разу не проверялось.

У политического центра не имелось силы, чтобы удержать золотой запас под своим контролем. С другой стороны, союзные государства, бросив Колчака, оказались в двойственном положении. С запада их поджимала Красная армия, а на Востоке расположились японские войска. Отдавать золото под контроль и тех, и других было не в их интересах, но и самим распорядиться не было возможности, поскольку путь их лежал на восток, через коммуникации, которые контролировались японцами. При этом в документах упоминается, что часть золота уже попала в их руки. Политический центр настроен оставить золото в России и предать его «нейтральной» советской власти. Чтобы золото было не вывезено, он предлагает всячески этому препятствовать [12, с. 16].

После передачи власти военно-революционному комитету 19 января 1920 г. последний издает приказ № 20 от 6 февраля за подписью председателя Ревкома Ширямова, в котором требует всем революционным организациям и партизанам на Восток от Иркутска не допускать движения поезда с золотым запасом «...открытым боем вырвать эти ценности из рук шайки грабителей кто бы они не были» [7, с. 42]. Революционный комитет предлагает чехам немедленно передать золотой запас России ему для его дальнейшей передачи Всероссийскому Советскому правительству. Чехам гарантируется содействие в их свободном продвижении на восток [8, с. 36]. 
23 января 1920 г. контроль над золотым запасом берет на себе комиссариат по охране золотых ценностей и золотого запаса [7, с. 37-38]. 24 января в их распоряжение поступают от коменданта г. Иркутска также мешок с золотом и бриллиантовыми вещами изъятым из вагона Колчака [7, с. 38].

Соглашение с чехами было достигнуто только 7-го февраля на ст. Куйтун. В соответствии с ним, чехи получали право на беспрепятственное продвижение на восток. Зона между красными войсками и чехами должна была составлять расстояние между деповскими станциями (Зима - Половина - Иннокентьевская - Слюдянка - Мысовая и т.д.) и она объявлялась нейтральной для ведения боевых действий. Колчак и его арестованные соратники передавались под контроль ревкома и советской власти. Пункт шестой данного соглашения предусматривал передачу золотого запаса революционному исполкому и до ухода последнего эшелона с чехами должен быть совместно охраняться караулом чехословацких и русских войск [7, с. 42-46].

19 февраля отделом Государственного контроля ставится вопрос о разработке специальной инструкции относительно отправки эшелона с золотом на запад. Эта работа должна предусматривать надлежащий осмотр технического состояния вагонов, порядок работ при перезагрузке и упаковке золота в деревянные ящики, охране, надзоре и ревизионном наблюдении [7, с. 73-75]. Основные вопросы были связаны с перезагрузкой золота из неисправных вагонов и упаковке золота в ящики, хранящегося до этого в мешках. Но чехи решение этих вопросов всячески затягивали.

Только 26 февраля отделом Государственного контроля утверждаются его представители по вопросам, возникающим при передаче золота. Представителем государственного контроля утверждается старший ревизор Н.А. Никольский, а его заместителем назначается ревизор ликвидационного контроля Березин. Одновременно утверждается и форма акта приема-передачи золотого запаса. Она предусматривала сравнение золотого запаса Волжско-камчатского коммерческого банка с золотым запасом Омского отделения ВКБ и соответственно принятым золотом в Иркутске [7, с. 79].

Наконец комиссия принимает решение приступить к перезагрузке золота 27 февраля. Передача золота должна начаться с головы состава, открывать при этом следовало не более двух вагонов. Все дефектные ящики следовало вкладывать в отдельные мешки и составлять по этому случаю отдельный акт. Проверка проводилась при участии чехов, но их роль сводилась к передаче вагонов по наружному осмотру пломб. Чехи в это время уже были готовы к отправке и могли отбыть в любой момент. По согласованию, комиссия в этом случае продолжала работать без их участия [7, с. 79-80]. 
Для перезагрузки золота были выделены специально подготовленные американские вагоны. В каждый американский вагон загружалось золото из трех вагонов.

Что в итоге? Золото было перегружено в 13 американских вагонов. Комиссия внимательно осматривала ящики, и в случае каких-либо повреждений фриксировала их как дефектные, требующие дополнительной проверки. Всего было выявлено 9 таких ящиков. Точно также поступали и с мешками. В этом случае они упаковывались дополнительно в новые мешки и пломбировались. 28 февраля при упаковке в новый мешок из одного мешка выкатилось 9 монет 10-рублевого достоинства. Дырку зашили, монеты поместили на место, новый мешок опломбировали. Позднее 3 марта комиссия пересчитала монеты в этом мешке. Все тысяча десятирублевых монет в нем оказались на месте [7, с. 96]. Общее количество мешков с золотом составило 1 678, ящиков с золотом - 5143. Не хватало 13 ящиков, которые были похищены 12 января. Позднее губернская газета «Власть Труда» сообщала, что кроме 13 ящиков при эвакуации был похищен еще мешок на 60000 р. [7, с. 113-114]. За время с 27 февраля по 3 марта было принято 5143 ящика и 1678 мешков и перегружено 13 вагонов американского типа. 22 марта поезд с золотом отправлен из Иркутска в Казань и 3 мая прибыл в Казань.

Кроме золота в поезде находилась и серебряная монета. Она была перевезена в кладовую Иркутского отделения госбанка. Всего 1206 ящиков обыкновенных, 176 больших, 323 плоских, 62 сумки, 75 мешков с серебряной и медной монетой. Причем 449 ящиков поступили из Красноярска (сдано Петропавловским отделением). Остальное вывезено из Омска, куда оно поступило из Самары в 1918 г. Их стоимость была приблизительно оценена в 3824 тыс. р. В 75 мешках находилась смесь медных и серебряных монет, оценить стоимость которых без подробного пересчета не представлялось возможным [8, с. 97-98]. Их пересчитали 4 мая [7, с. 105-107].

Если произвести несложные расчеты, то из Казани и Самары в Омск было вывезено 32563 пуда золота или 521,008 т на сумму 651532117 р. Обратно отправлено 327,564 т. на сумму 409526103 р. К этой сумме необходимо добавить 389 кг золота сплавочной лаборатории, которые были отправлены в Читу, куда было эвакуировано омское отделение Государственного банка (на сумму 486568 р.) [2; 6]. К отправке этого золота Колчак и его правительство уже не имели отношения. Таким образом золотой запас России Колчак за год уменьшил на 193,049 т., или почти на $37 \%$. Из справки, же составленной в июне 1921 г. Народным комиссариатом финансов РСФСР, следует, что за период правления Колчака золотой запас России сократился на 235,6 млн р., или 182 т [9].

Таким образом можно констатировать, что никакого мифического «золота Колчака», похищенного и тайно сохраненного, не имеется. Ис- 
следователям, которые занимались данной проблемой, это хорошо известно. Есть конкретные данные о грабеже золотого запаса со стороны семеновцев, а также Франции, Великобритании, США и Японии. Золотой запас сопровождался чиновниками Госбанка, которые стремились отразить полный учет в движении золота. Документами подтверждается, что за период, когда золой запас находился в руках правительства Колчака, отчетность о его движении сопровождалась соответствующими документами. Но подтверждается она в общем, но не деталях. Разночтений в деталях в исторической литературе остается множество. Они имеют отношение к причастности в этих событиях отдельных людей, количеству составов и вагонов, в которых перевозилось золото, процессу его доставки до Омска, а затем до Иркутска, количеству похищенного золота и др. И это дает почву для различных околонаучных версий, относительно возможного нахождения «похищенного» золота. Думается, что издание сборника документов из фондов Государственного архива Иркутской области «Из истории золотого запаса адмирала Колчака» позволяет расставить акценты в этой теме, несмотря на сохраняющиеся разночтения в деталях. Гораздо интереснее сегодня другое. Данными о золотом запасе Российской империи советское правительство широко оперировало еще в 1922 г. на Генуэзской конференции. Там же приводились данные и о присвоенном государствами Антанты золоте, которое оказалось в руках Колчака. То есть уже спустя два года эту тему советское правительство широко использовало для укрепления своих позиций на международной арене и отстаивания национально-государственных интересов. Совсем другая история с золотым запасом Советского Союза. Прошло уже почти три десятка лет после распада СССР, но о судьбе его золота, субъектах присвоения не известно ничего. Нет ни публикаций, ни сборников документов, ни монографий. И это выглядит слишком контрастно на фоне истории вокруг золота российской империи.

\section{Список использованной литературы и источников}

1. Адмирал Колчак. Протоколы допроса. С предисловием Николая Старикова [Протоколы заседаний Чрезвычайной следственной комиссии (21 января 6 февраля 1920 г.)]. - СПб. : Питер, 2015. - 272 с.

2. Гак А. Гражданская война и золотой запас России [Электронный ресурс] / А. Гак // Наука и жизнь. - 2001. - № 9. - Режим доступа : https://www.nkj.ru/ archive/articles/6820/

3. Голуб П. А. С кого они портреты пишут: (Об истинном лице колчаковщины) / П. А. Голуб // Военно-исторический журнал. - 1992. — № II. - С. 81-85.

4. Гудошников М. А. Очерки из истории гражданской войны в Сибири / М. А. Гудошников. - Иркутск : Кн. изд-во, 1959. - 204 с.

5. Дроков С. В. Адмирал Колчак и суд истории / С. В. Дроков. - М. : Центрполиграф, 2009. - 591 с.

6. Золотой запас // Власть труда. - 1920. - 23 апр. - С. 7. 
7. Из истории золотого запаса адмирала Колчака : Сборник документов из фондов Государственного архива Иркутской области / отв. за выпуск Е. В. Ильина. - Иркутск : Изд-во «Оттиск», 2017. - 156 с.

8. Колчак и интервенция на Дальнем Востоке : Документы и материалы. Владивосток : Наука, 1995. - 216 с.

9. Лапидус М. Судьба золотого запаса царской России [Электронный ресурс] / М. Лапидус, Ю. Головин // Вестник. — 1999. — № 23 (230), 24 (231). — Peжим доступа : http://www.vestnik.com/issues/1999/1109/win/lapidus.htm

10. Плотников И. Ф. Александр Васильевич Колчак. Исследователь, адмирал, Верхов. правитель России / И. Ф. Плотников. - М. : Центрполиграф, 2002. $-264 \mathrm{c}$.

11. Серебренников В. Золотой запас России / В. Серебренников // Иркутская старина. - 1994. - Вып. 2. - С. 14-21.

12. Сироткин В. Г. Вернется ли на родину российское золото / В. Г. Сироткин // Знамя. - 1992. - № 3. - С. 13-21.

13. Шалак А. В. Некоторые историко-геополитические штрихи к портрету А.В. Колчака / А. В. Шалак // Иркутский историко-экономический ежегодник: 2017. - Иркутск : Изд-во БГУ, 2017. - С. 96-112.

\section{Информация об авторе}

Шалак Александр Васильевич - доктор исторических наук, профрессор, заведующий кафедрой истории и международных отношений, Байкальский государственный университет, 664003, г. Иркутск, ул. Ленина, 11; e-mail: Shalak-AV@bgu.ru

\section{Author}

Alexander V. Shalak - Doctor of History, Professor, Head of the Chair of History and International Relations, Baikal State University, 11 Lenin Str., 664003, Irkutsk, Russia; e-mail: Shalak-AV@bgu.ru 